\title{
CONSTITUTIONAL STATUTES AND IMPLIED REPEAL: THE THOBURN DECISION AND THE CONSEQUENCES FOR NEW ZEALAND
}

\author{
Rebecca Prebble*
}

The United Kingdom case of Thoburn v Sunderland City Council suggests that there might be statutes that may not be impliedly repealed because of their "constitutional" status. This article examines the Thoburn decision and considers its implications for both the United Kingdom and New Zealand. This article questions whether Thoburn can be applied directly to New Zealand's constitutional situation, and in particular whether New Zealand even has statutes that might be called "constitutional". The role of the New Zealand Bill of Rights Act 1990 is considered, as is the case of $\mathrm{R} v$ Pora, which can be seen as New Zealand's forerunner to Thoburn.

The article also examines the broader significance of the Thoburn decision and its implications for parliamentary sovereignty. Thoburn can be seen as a mid-point between the traditional supremacy of Parliament and a more rights-based jurisprudence because it protects rights without fettering Parliament's ability to legislate.

\section{INTRODUCTION}

\section{A Traditional Implied Repeal}

When Parliaments repeal legislation they generally make their intentions both express and clear. ${ }^{1}$ Sometimes, however, Parliaments enact laws that are inconsistent with existing statutes. A L Smith $\mathrm{J}$ set out the courts' traditional response in Kutner $v$ Philips. $^{2} \mathrm{He}$ said that "[i]f ... the provisions of a later enactment are so inconsistent with or repugnant to the provisions of an earlier

* Submitted as part of the LLB(Hons) programme at Victoria University of Wellington. Winner of the Robert Orr McGechan Memorial Prize.

1 For example, the Corrections Act 2004, s 208(1) which expressly repeals a number of enactments.

2 Kutner v Philips [1891] 2 QB 267 (QB). 
one that the two cannot stand together, the earlier is abrogated by the later". ${ }^{3}$ That is, the later statute impliedly repeals the earlier one to the extent of the inconsistency.

For a court to hold that Parliament has repealed one of its own statutes without expressly saying so is a drastic step. For this reason, courts faced with apparently conflicting statutes should strive to reconcile them, only holding that there has been an implied repeal as a last resort. ${ }^{4}$ There are a number of ways in which courts may avoid an implied repeal or at least may reduce an implied repeal's effect. For example, where the earlier statute is specific in application and the later one is general, the courts may conclude that Parliament has not intended that the later Act should apply to the circumstances to which the earlier one relates. ${ }^{5}$ Conversely, where a later specific rule is inconsistent with an earlier general one, implied repeal operates only "pro tanto", that is, only to the extent that the Acts are inconsistent, with the general rule preserved as much as possible. ${ }^{6}$

\section{B Analytical Framework}

The traditional doctrine of implied repeal has recently been challenged in a number of jurisdictions. Where once implied repeal affected all statutes equally, there are now suggestions that there are certain types of statutes that are immune from implied repeal and can be repealed only by express enactment. For example, the Canadian Supreme Court has held that human rights legislation has a "special nature" that protects it from implied repeal. ${ }^{7}$ More recently, the United Kingdom case of Thoburn v Sunderland City Council has recognised a class of "constitutional" statutes that cannot be impliedly repealed. ${ }^{8}$

This article examines the extent to which Thoburn challenges parliamentary sovereignty and explores the consequences of the identification of a class of constitutional statutes. It considers the effect that a Thoburn-type rule would have on New Zealand law, particularly in relation to the New Zealand Bill of Rights Act 1990 and discusses the case of $R v$ Pora,${ }^{9}$ which addressed the interaction between fundamental rights and implied repeal. Is a rule protecting constitutional statutes

3 Kutner v Philips, above n 2, 272 A L Smith J.

4 Kutner v Philips, above n 2, 272 A L Smith J; see also Paine v Slater (1883) 11 QBD 120, 122 (EWCA) Brett LJ.

5 See for example, Cox v Hakes (1890) 15 AC 506, 517 (HL) Lord Halsbury; Bishop of Gloucester v Cunningham [1943] KB 101, 105 (CA) Lord Greene MR, Scott and MacKinnon LJJ.

6 See Goodwin v Philips (1908) 7 CLR 1, 7 (HCA) Griffith CJ; $R$ v Pora, [2001] 2 NZLR 37, para 44 (CA) Elias CJ and Tipping J.

7 Craton v Winnipeg School Division (No 1) [1985] 2 SCR 150, para 8 McIntyre J for the Court.

8 Thoburn v Sunderland City Council [2003] QB 151 (Div Ct).

$9 \quad R v$ Pora, above $\mathrm{n} 6$. 
from implied repeal likely to be adopted in New Zealand? More fundamentally, how can New Zealand's constitutional statutes be identified?

The final section of the article considers whether any legal limit on parliamentary sovereignty is philosophically desirable, even when that limit comes from constitutional rights. This article argues that the minimal erosion of parliamentary sovereignty that a revision of implied repeal represents is a beneficial constitutional development, because it preserves a democratically elected Parliament's power to repeal legislation expressly, yet recognises that there are fundamental rights that should be protected to some degree.

\section{Relationship with Parliamentary Sovereignty}

Implied repeal is an example of the constitutional doctrine of parliamentary sovereignty in action. ${ }^{10}$ If Parliament has full power to make law, then that power cannot be affected by any prior Act passed by a previous Parliament. To hold a provision of an Act to be ineffective because it conflicts with an earlier Act would be to hold that Parliament's law-making power can be curtailed by the legislative actions of an earlier Parliament.

It has been suggested that parliamentary sovereignty does not necessarily require the courts to give effect to later statutes in preference to earlier ones if there are indications that Parliament did not in fact mean the later statute to prevail over the earlier one, ${ }^{11}$ but in the absence of such indications courts must apply Parliament's most recent statement of its intent.

Traditionally, courts reject attempts by Parliaments to pass Acts that purport to override future Acts. In Ellen Street Industries Ltd v Minister of Health, a provision that stipulated that all provisions that were inconsistent with it "shall cease to have or shall not have effect"12 was pronounced ineffective because "it is impossible for Parliament to enact that in a subsequent statute dealing with the same subject matter there can be no implied repeal". ${ }^{13}$ Parliament's continuing power to make law means that Parliament has the power impliedly or expressly to repeal any Act. ${ }^{14}$

In jurisdictions like New Zealand and the United Kingdom with constitutions that hew to Diceyan theory, courts have traditionally not thought that one form of legislation is any more or less vulnerable to repeal than another, whether that repeal is express or implied. In 1920, this principle

10 See Philip Joseph Constitutional and Administrative Law in New Zealand (2 ed, Brookers, Wellington, 2001) 482 ["Constitutional and Administrative Law in New Zealand"].

11 Andrew Butler "Implied Repeal, Parliamentary Sovereignty and Human Rights in New Zealand" [2001] PL $586,594$.

12 Acquisition of Land (Assessment of Compensation) Act 1919 (UK), s 7.

13 Ellen Street Industries Ltd v Minister of Health [1934] 1 KB 590, 597 (CA) Maugham LJ.

14 Ellen Street Industries Ltd v Minister of Health, above n 13, 597 Maugham LJ; see also Vauxhall Estates Ltd v Liverpool Corporation [1932] 1 KB 733, 744 (KB) Avory J. 
applied even to the Australian Constitution Act $1867 .{ }^{15}$ However, the growing emphasis on human rights in both legal systems has rendered this strict Diceyan view increasingly open to question. It is argued that both New Zealand and the United Kingdom have statutes and provisions that may be described as "constitutional", with the result that these statutes and provisions may not be impliedly repealed.

\section{IMPLIED REPEAL IN THOBURN}

\section{A Facts}

Thoburn was heard in the United Kingdom Divisional Court. ${ }^{16}$ The case concerned the somewhat mundane issue of permissible units of measurement in the United Kingdom. It involved the appeals of three grocers who were prosecuted for using imperial measurements instead of metric ones, and the appeal of a fourth grocer from his local council's decision not to renew his trading licence for the same reason. Both the prosecutions and the withholding of the licence were under the authority of the Units of Measurement Regulations 1994, which purported to prohibit the use of imperial measurements in trade.

The appellants contended that the 1994 regulations were ultra vires because the empowering legislation had been impliedly repealed before the 1994 regulations were passed. To understand this argument it is necessary to survey a tangled web of primary and subordinate legislation.

The first relevant law was the European Communities Act 1972. That Act gave the United Kingdom executive the power to amend primary legislation by Order in Council so as to make the legislation consistent with any European Community Directives that might be issued. ${ }^{17}$ The United Kingdom then passed the Weights and Measures Act 1985. This Act permitted the use of both imperial and metric measurements in trade. ${ }^{18}$ The appellants argued that by explicitly permitting the use of imperial measurements in trade, the Weights and Measures Act impliedly repealed the broad power that section 2(2) of the European Communities Act conferred on the executive to the extent that the executive no longer had the power to prohibit the use of imperial measurements in trade.

The Units of Measurement Regulations 1994 purported to amend the Weights and Measures Act by prohibiting the use of imperial measurements in trade after 2000. The regulations permitted the use of imperial measurements in the intervening period, provided that the imperial measurements were supplementary to metric ones. The Units of Measurement Regulations 2001 subsequently amended the original date; so that imperial measurements were permitted as supplementary

15 McCawley v R [1920] AC 691, 704 (PC) Lord Birkenhead.

16 Thoburn v Sunderland City Council, above n 8.

17 European Communities Act 1972 (UK), s 2(2) and (4).

18 Weights and Measures Act 1985 (UK), s 1. 
indicators until 2010. The grocers were convicted during the interim period because they displayed only imperial measurements.

The regulations were made pursuant to the power delegated by the European Communities Act. They followed a European Community Directive that directed Member States to phase out the use of imperial measurements in trade. ${ }^{19}$ The appellants argued that the 1994 regulations were ultra vires because they were made pursuant to a power that had been impliedly repealed.

Laws LJ found against the four grocers. ${ }^{20}$ For there to be an implied repeal there must be an inconsistency between two statutes, and Laws LJ found that there was no such inconsistency. The executive's power to amend legislation inconsistent with European Community Directives extended to legislation passed after the power was delegated, and therefore the provisions of the Weights and Measures Act were not inconsistent with a power to change that same Act. ${ }^{21}$ Laws LJ supported his decision by a second ground: even if there were an inconsistency between the two Acts, the Weights and Measures Act could not impliedly repeal the European Communities Act because of the special nature of the latter. The European Communities Act was a constitutional statute and as such could be repealed only by express legislative pronouncement. For there to be an implied repeal, it is only necessary that there should be an irreconcilable inconsistency between two statutes. This situation does not amount to an express legislative pronouncement. ${ }^{22}$ Thus we arrive at the proposition that constitutional statutes cannot be impliedly repealed. That proposition is the focus of this article.

\section{B The United Kingdom Constitutional Framework}

The Thoburn decision neatly ties together two parallel United Kingdom constitutional developments: the supremacy of European Union law, and the emergence of "common law constitutionalism". By joining the European Union, member states limit their sovereign rights, "albeit within limited fields". ${ }^{23}$ As Laws LJ acknowledges, the practical result of this limitation of sovereignty is that the substantive European Union rights that the European Communities Act

19 Council Directive (EEC) 89/617 on the approximation of the laws of the Member States relating to the units of measurement [1989] OJ L-357.

20 The other Judge in Thoburn, Crane J, agreed with Laws LJ, see Thoburn v Sunderland City Council, above n 8 , para 85 Crane $\mathrm{J}$.

21 Thoburn $v$ Sunderland City Council, above n 8, para 50 Laws LJ. For a further discussion of the constitutional issues surrounding the delegation to the executive of the power to amend primary legislation, see Geoffrey Marshall "Metric Measures and Martyrdom by Henry VIII Clause" (2002) 118 LQR 493, and Alison Barber and N Young "The Rise of Prospective Henry VIII Clauses and their Implications for Sovereignty" [2003] PL 112.

22 Thoburn v Sunderland City Council, above n 8, para 63 Laws LJ.

23 Case 26/62 NV Algemene Transport - en Expeditie Onderneming van Gend en Loos v Nederlandse administratie der belastingen [1963] ECR 1, 12. 
incorporates "rank supreme" in the United Kingdom, even over primary legislation. ${ }^{24}$ The issue that Thoburn grapples with is how domestic statutes that incorporate European Union rights should be treated.

The real problem lies in the uneasy relationship between parliamentary sovereignty and the supremacy of European Union law. The attitude that "whatever limitation of its sovereignty Parliament accepted when it enacted the European Communities Act was entirely voluntary" 25 does little to resolve the question of how international developments may affect domestic sovereignty. ${ }^{26}$

Laws LJ rejects any suggestion that European Union law itself could elevate a purely domestic statute to constitutional status, holding that "there is nothing in the 1972 Act which allows the [European] Court of Justice ... to touch or qualify the conditions of Parliament's legislative supremacy in the United Kingdom". ${ }^{27}$ Laws LJ finds that Parliament's legislative supremacy has indeed been touched, but in a manner "wholly [consistent] with constitutional principle", that is, by the common law. ${ }^{28}$

This inspired piece of reasoning allows Laws LJ to accommodate the fundamental shift in constitutional arrangements brought about by European Union law squarely within established constitutional principles. If Parliament's sovereignty is to be altered, that alteration must come from the common law, because the domestic courts are the body "to which the scope and nature of parliamentary sovereignty are ultimately confided". ${ }^{29}$ Furthermore, Thoburn gives legal recognition to the political reality that the European Union has had a fundamental effect on the rights of the United Kingdom population.

The other constitutional movement that impinges on Laws LJ's reasoning is the development of the common law constitutionalism theory. This theory holds that the common law is the ultimate source and guardian of rights and constitutional politics centre on the courts (as opposed to on Parliament or the executive). ${ }^{30}$ The influence of this idea can be seen in a number of recent United Kingdom administrative law judgments, where the courts have held that the ambits of empowering clauses that authorise administrative action may be curtailed by principles of legality that originate

24 Thoburn v Sunderland City Council, above n 8, para 69 Laws LJ.

$25 R v$ Secretary of State for Transport, ex parte Factortame Ltd (No 2) [1991] AC 603, 658-659 (HL) Lord Bridge of Harwich.

26 Mark Elliot "United Kingdom: Parliamentary Sovereignty Under Pressure" (2004) 2 ICon 545, 548

27 Thoburn v Sunderland City Council, above n 8, para 59 Laws LJ.

28 Thoburn v Sunderland City Council, above n 8, para 59 Laws LJ.

29 Thoburn $v$ Sunderland City Council, above n 8, para 60 Laws LJ.

30 See for example, Thomas Poole "Back to the Future? Unearthing the Theory of Common Law Constitutionalism" (2003) 23 OJLS 435, 437. 
in the common law. ${ }^{31}$ These principles of legality cannot be derived from any literal reading of the statutes involved. ${ }^{32}$ Legislative will is therefore no longer seen as an unqualified value, but rather as "informed by our most deep-seated constitutional values", which originate in the common law. ${ }^{33}$

The idea that the United Kingdom constitution is founded on common law rights is apparent in the Thoburn decision. Laws LJ holds that because the common law recognises constitutional rights, it is appropriate that constitutional statutes should also be recognised and afforded special protection. ${ }^{34}$ Laws LJ holds that his new formulation of implied repeal strikes the appropriate balance between fundamental rights and legislative supremacy, because it preserves parliamentary sovereignty while allowing the United Kingdom "most of the benefits of a written constitution, in which fundamental rights are accorded special respect". 35

\section{Identification of Constitutional Statutes}

According to Laws LJ, a constitutional statute is one that "(a) conditions the legal relationship between citizen and state in some general, overarching manner, or (b) enlarges or diminishes the scope of what we would now regard as fundamental constitutional rights". ${ }^{36}$ This test is necessarily vague, and appears susceptible to as wide or as narrow an interpretation as individual judges choose to give it. ${ }^{37}$ Nevertheless, Laws LJ does suggest ways in which other statutes might be identified as falling into the category of "constitutional".

Laws LJ holds that statutes that give effect to "rights which should properly be classified as constitutional or fundamental", so designated by the common law, should themselves have some sort of constitutional status. ${ }^{38}$ Some of the examples of such statutes that Laws LJ gives are the Magna Carta 1297, the Union with Scotland Act 1706, the Human Rights Act 1998, and the Government of Wales Act 1998. ${ }^{39}$

31 See for example, $R v$ Secretary of State for the Home Department, Ex parte Simms [2000] 2 AC 115 (HL); $R$ $v$ Secretary of State for the Home Department, Ex parte Pierson [1998] AC 539 (HL).

32 T R S Allan "Constitutional Dialogue and the Justification of Judicial Review" (2003) 23 OJLS 653, 574.

33 Allan, above n 32, 569.

34 Thoburn v Sunderland City Council, above n 8, para 63 Laws LJ.

35 Thoburn v Sunderland City Council, above n 8, para 64 Laws LJ.

36 Thoburn v Sunderland City Council, above n 8, para 62 Laws LJ.

37 Marshall, above n 21, 496.

38 Thoburn $v$ Sunderland City Council, above n 8, para 62 Laws LJ.

39 Thoburn v Sunderland City Council, above n 8, para 64 Laws LJ. 


\section{Why is the European Communities Act Constitutional?}

Laws LJ's test for constitutional status proposes two ways in which a statute might be constitutional. His Lordship holds that most instances of category (b) will also fall under limb (a). ${ }^{40}$ It appears that the converse is not true: not all instances of category (a) will also be instances of category (b).

The European Communities Act itself can be seen as a constitutional statute that falls under limb (a) because it "conditions the legal relationship between citizen and state in some general, overarching manner". ${ }^{41}$ The European Communities Act quite clearly fits under limb (a): the creation of a new and superior legal system is a fairly dramatic development, and, as Laws LJ says, "[i]t may be there has never been a statute having such profound effects on so many dimensions of our daily lives". ${ }^{42}$ Nevertheless, the European Communities Act does not fall under limb (b) because it does not appear to be concerned with fundamental rights.

Fundamental rights, then, are a sufficient condition for constitutional status, but not a necessary one. This aspect of Thoburn means that some of the provisions that Laws LJ would protect against implied repeal are not the sorts of provisions that we normally think of as fundamental. The provision Thoburn was concerned with, the metric system rule, is an example. No one would suggest that there is a fundamental right to use the metric system, yet the metric system rule has somehow achieved constitutional status.

This result appears less anomalous when we look at the metric system rule in the wider constitutional context. The metric system rule is not just an ordinary rule; it is a rule that has the full force of European Union law behind it. The rule that the metric system is to be used as the primary system in trade has more significance than its plain words suggest: in making the rule the United Kingdom was fulfilling its international obligations. Those international obligations are so important that they brought about a change in the United Kingdom's constitutional structure.

\section{E What About Constitutional Provisions?}

The Thoburn decision does not address the possibility of an inconsistency involving a single provision that may be classed as constitutional, as opposed to a whole constitutional statute. Constitutionally important provisions might well be contained in ordinary statutes: does Thoburn extend protection from implied repeal to such provisions?

While Thoburn considers only the circumstances in which an entire Act may be designated as constitutional, a logical extension of the decision is that individual provisions may be protected from

\footnotetext{
40 Thoburn v Sunderland City Council, above n 8, para 62 Laws LJ.

41 Thoburn v Sunderland City Council, above n 8, para 62 Laws LJ.

42 Thoburn v Sunderland City Council, above n 8, para 62 Laws LJ.
} 
implied repeal whether or not they are contained in a constitutional statute. If Laws LJ is correct in stating that his decision means that "fundamental rights are accorded special respect", ${ }^{43}$ his revision of the traditional doctrine of implied repeal must extend to individual provisions that protect fundamental rights.

This logical extension means that Thoburn really proposes two ways in which a provision may be insulated against implied repeal. The first way is simply by virtue of being contained in a constitutional statute. Once an Act has passed Laws LJ's test for constitutional status, all the provisions of the Act are protected from implied repeal. Thus, the metric system rule is protected against implied repeal simply because it is contained in a constitutional statute: the European Communities Act.

The second way in which a provision might be protected against implied repeal is that the provision itself might qualify as constitutional because it embodies a fundamental right. Thoburn only dealt with how constitutional Acts may be identified; how individual provisions might attain that status is an open question. Nevertheless, because Laws LJ holds that the existence of constitutional Acts "follows the special status of constitutional rights", ${ }^{44}$ we can hypothesise that any provision guaranteeing a constitutional right might be considered constitutional for the purposes of implied repeal.

\section{F Parliamentary Sovereignty}

Laws LJ justifies his revision of implied repeal by pointing out that the courts are the body "to which the scope and nature of parliamentary sovereignty are ultimately confided" ${ }^{45}$ It is clear, then, that Laws LJ understands that his decision limits parliamentary sovereignty. In creating a class of constitutional statutes that are invulnerable to implied repeal, Laws LJ has effectively told Parliament that the courts will not give effect to some exercises of Parliament's legislative power. This judicial act seems only a few degrees removed from actually declining to apply particular statutes.

Nevertheless, it is important to look beyond Laws LJ's language and to determine exactly how much this reformulation of implied repeal limits parliamentary sovereignty. The cardinal purpose of statutory interpretation is "to ascertain what Parliament meant by using the language of the statute". ${ }^{46}$ A revision of implied repeal only challenges parliamentary sovereignty to the extent that Parliament's intention is thwarted. If Laws LJ is correct in holding that laws concerning individual rights have attained a special status in the legal system, one might conclude that Parliament would

43 Thoburn v Sunderland City Council, above n 8, para 64 Laws LJ.

44 Thoburn v Sunderland City Council, above n 8, para 60 Laws LJ.

45 Thoburn v Sunderland City Council, above n 8, para 60 Laws LJ.

46 MacNiven (Inspector of Taxes) v Westmoreland Investments Ltd (2001) TC 1, para 29 (HL) Lord Hoffmann. 
not want the courts to abrogate those rights in the absence of express direction. On this view, a court holding that constitutional statutes could be impliedly repealed after all would be placing a greater limit on parliamentary sovereignty than the Thoburn decision.

The contrary argument is that implied repeal is only available as a tool of statutory interpretation in the last resort. ${ }^{47}$ Situations where implied repeal potentially arises are those where the language of both statutes is clear, but the two statutes cannot be read together. That is, the intention behind the later statute will usually be obvious. Moreover, the high importance of "constitutional" statutes makes it unlikely that Parliament would ever be unaware of the existence of such statutes and the rights that they guarantee. Parliament is therefore unlikely to override them inadvertently by later inconsistent legislation. Rather, any purported implied repeal is likely to be exactly what Parliament intended.

\section{WHAT DOES THOBURN MEAN FOR NEW ZEALAND?}

\section{A Parliamentary Sovereignty in New Zealand}

New Zealand courts have tended to reject any suggestion that Parliament might be bound in any way. As recently as 1999, the Court of Appeal held that the Magna Carta placed no restrictions on what Parliament could legitimately enact, ${ }^{48}$ although the Court did not fully canvass the issue of whether there could ever be a category of laws that enjoy a status higher than other laws. ${ }^{49}$

Despite the Court of Appeal's respectful nod in the direction of Parliament, the trend in New Zealand is to describe the branches of government as "engaged in a joint enterprise discharging different task-specific functions", ${ }^{50}$ rather than to focus on the "who is sovereign?" question. This trend seems to have been sparked largely by judges writing extra-judicially rather than by actual decisions. As long ago as 1988, the President of the Court of Appeal (as he then was) suggested that constitutional debates needed to be refocused towards the question of exactly which values could potentially limit legislative power, and away from the more abstract question of whether that power could be limited at all. ${ }^{51}$

The learned President's reasoning was stipulative rather than strictly logical. After all, the question of whether legislative power can be limited is an issue prior to the question of which values might do the limiting. "Refocusing" debate towards the second question does not provide an answer to the first, but was a strategy that allowed the President to proceed as if the first question

47 Kutner v Philips, above n 2, 272 A L Smith J.

48 Shaw v Commissioner of Inland Revenue [1999] 3 NZLR 154 (CA).

Shaw v Commissioner of Inland Revenue, above n 48, para 17 Judgment of the Court.

50 Philip Joseph "Constitutional Statutes and Implied Repeal" [2003] NZ Law Rev 416, 418.

51 Rt Hon Sir Robin Cooke "Fundamentals" [1988] NZLJ 158, 164. 
had been settled definitively in the affirmative. In spite of its absence of foundation, this sort of reasoning is not uncommon. Also writing extra-judicially, Elias CJ recently echoed Lord Cooke's approach. The Chief Justice argued that New Zealand has moved away from the mindset that there must be one supreme source of power in its constitution. To Elias CJ, it seemed that the identification of such a power was rather pointless. ${ }^{52}$

Extra-judicial campaigns notwithstanding, the idea that Parliament is sovereign remains orthodox. Despite claims that parliamentary sovereignty is an "obsolete and inadequate"53 constitutional doctrine, on the rare occasions where litigation calls parliamentary sovereignty into question, the judiciary resolutely defends it. ${ }^{54}$ The Thoburn decision, if followed in New Zealand, would represent more than a merely theoretical change to New Zealand's constitution. ${ }^{55}$

\section{B Status of Implied Repeal}

There is no doubt that the doctrine that Parliament can repeal legislation by implication by passing an inconsistent law is a part of New Zealand law, ${ }^{56}$ but it is arguable that the doctrine is now seen as a truly undesirable method of resolving statutory inconsistencies. Implied repeal has always been a last resort tool of statutory interpretation, available only when other methods fail to resolve an inconsistency between two provisions ${ }^{57}$ Now, implied repeal is still a last resort, but the list of statutory interpretation tools available before resort to implied repeal has grown. Most notably, the New Zealand Bill of Rights Act 1990 has become a tool of statutory interpretation and can be used to resolve inconsistencies between statutes without the need for implied repeal.

It is relatively uncommon for litigants to invoke the doctrine of implied repeal, and particularly uncommon for them to be successful. Parliament presumably tries to not enact legislation that is inconsistent with prior law. Cases where arguments based on implied repeal have failed tend to hold that the two relevant Acts can in fact be read together. ${ }^{58}$ Despite the paucity of cases dealing with

52 Rt Hon Dame Sian Elias "Sovereignty in the $21^{\text {st }}$ Century: Another Spin on the Merry-go-round" (2003) 14 PLR 148, 149 ["Sovereignty in the $21^{\text {st }}$ Century"].

53 Sian Elias "The Treaty of Waitangi and the Separation of Powers in New Zealand" in B D Gray and R B McClintok (eds) Courts and Policy: Checking the Balance (Brookers, Wellington, 1995) 206, 224.

54 See for example, $R v$ Pora, above n 6, para 113 Keith, Gault and McGrath JJ.

55 For general exploration of the current tension in New Zealand between Parliamentary sovereignty and judicial activism, see Matthew S R Palmer "Some Realism about Relevance: Who Interprets New Zealand's Constitution?" Paper presented to the New Zealand Centre for Public Law's Second Annual Conference on the Primary Functions of Government (Wellington, 2004) 11-13.

56 For example, Henderson Borough Council v Auckland Regional Authority [1984] 1 NZLR 16 (CA) applied the doctrine.

57 Kutner v Philips, above n 2, 275 A L Smith J.

58 See for example, Smith Kline \& French Laboratories Ltd v Attorney-General [1991] 2 NZLR 560 (CA); $R v$ Howe [1982] 1 NZLR 618 (CA). 
implied repeal, a recent New Zealand case is particularly relevant to Thoburn. The case of $R v$ Pora concerned the exact issue that Thoburn seeks to resolve, ${ }^{59}$ that is, whether constitutional rights can be impliedly repealed.

\section{R v Pora}

Pora concerned the possible retrospective application of the Criminal Justice Amendment Act (No 2) $1999 .{ }^{60}$ The amendment provided that in cases of murder involving home invasion sentencing judges were obliged to impose a minimum non-parole period of at least 13 years. ${ }^{61}$ This amendment purported to have retrospective effect, that is, it had the effect of imposing a penalty on some offenders that was not available at the time when the offence was committed.

The amendment directly conflicted with the Act that it amended, which provided elsewhere that notwithstanding any rule of law to the contrary, courts had no power to order a penalty that could not have been imposed on the offender at the time of the offence. ${ }^{62}$ The issue in Pora was therefore whether the amending provision impliedly repealed the earlier non-retrospecitvity provision to the extent of creating a specific exception to the earlier general rule.

\section{Implied Repeal in Pora}

Pora was convicted in 1994 of a murder involving a home invasion that was committed in 1992. His conviction was set aside, but he was reconvicted in 2000 after a second trial. The sentencing judge imposed a 13-year non-parole period even though that penalty was not available at the time that Pora committed the offence. Pora appealed to the Court of Appeal, arguing that the retrospective provisions of the amending Act had no effect because of the general Criminal Justice Act 1985 provision that penalties must be imposed prospectively. One of the Crown's counterarguments was that because the amending Act was passed after the general non-retrospectivity provision, it repealed the non-retrospectivity provision to the extent of the inconsistency.

Pora's appeal was heard by a seven-judge Court of Appeal. Three judges, Keith, Gault and McGrath JJ, found that the amending provision had impliedly repealed the non-retrospectivity provision of the Criminal Justice Act to the extent that the two provisions were inconsistent. That is, the amending Act was a specific exception to the general non-retrospectivity rule. ${ }^{63}$

$59 \quad R$ v Pora, above n 6.

60 An earlier case, $R v$ Poumako [2000] 2 NZLR 695 (CA), dealt with the same issue. $R v$ Pora, above $\mathrm{n} 6$, is more relevant for the purposes of this article.

61

Criminal Justice Amendment Act (No 2) 1999, s 2(4).

62 Criminal Justice Act 1985, s 2(4).

$63 R v$ Pora, above n 6, para 116 Keith, Gault and McGrath JJ. 
While Keith, Gault and McGrath JJ held that the amending provision operated retrospectively, they also held that the provision's retrospective application was limited to the point at which judges were first empowered to impose minimum non-parole periods. ${ }^{64}$ Pora committed his offence before judges were given this power so the mandatory non-parole period of thirteen years did not apply to Pora and his appeal was allowed.

Elias CJ and Tipping J, and Thomas $\mathrm{J}$ in a separate concurring judgment, also allowed Pora's appeal but arrived at their conclusion by a markedly different path. Elias CJ and Tipping J held that because the conflicting provisions were contained in a single statute, the traditional doctrine of implied repeal was an inappropriate interpretation tool. Their Honours held that when provisions within one statute are inconsistent, the correct approach is to look at all the circumstances and to determine which provision should give way. ${ }^{65}$ Elias CJ and Tipping $\mathrm{J}$ held that the dominant provision of the Criminal Justice Act was the provision that forbade retrospective penalties. The amending provision had to yield, and was therefore deprived of retrospective effect. ${ }^{66}$ The seventh judge, Richardson P, agreed with Keith, Gault and McGrath JJ to the extent that the amending provision could not apply to Pora. Richardson P did not decide whether the amending provision had any affect at all. ${ }^{67}$

\section{E Are the Approaches of Elias CJ, Tipping and Thomas JJ Legitimate?}

The judgment of Elias CJ and Tipping J raises the question of why implied repeal should not be capable of operating within a single statute, particularly where the earlier provision is general and the later one is specific. An amending provision is presumably just as good an indicator of parliamentary intent as a new Act. In fact, Parliament is less likely to inadvertently overlook a conflicting provision in the very Act it is amending than it is to overlook a conflicting provision in the body of legislation generally. Elias CJ and Tipping J do not attempt to justify the distinction that they draw, and it is tempting to conclude that the real reason why these judges rejected implied repeal is that the provision that would have been repealed was one that guaranteed a constitutional right. Elias CJ and Tipping J may have felt that the proposition that constitutional statutes cannot be impliedly repealed was better hedged around than baldly stated. ${ }^{68}$

$64 R v$ Pora, above n 6, para 110 Keith, Gault and McGrath JJ.

$65 R$ v Pora, above n 6, para 4 Elias CJ and Tipping J.

$66 R$ v Pora, above $\mathrm{n}$ 6, para 49 Elias CJ and Tipping J.

$67 \quad R$ v Pora, above n 6, paras 59-60 Richardson P.

68 The third minority judge, Thomas $\mathrm{J}$, in fact came very close to saying that constitutional statutes cannot be impliedly repealed. See $R v$ Pora, above n 6, para 169 Thomas J and Part VI D Statutory Interpretation. 
Elias CJ, Tipping and Thomas JJ have been criticised for refusing to apply a provision that the legislature obviously intended to enact. ${ }^{69}$ It is undeniable that the judgments, especially that of Elias CJ and Tipping J, employ extremely artificial justifications for their refusal to apply the normal tools of statutory interpretation. In particular, Elias CJ and Tipping J's insistence that the situation was simply that of an inconsistency within a single statute ignores the reality that the amendment was passed fourteen years after the principal Act. ${ }^{70}$ Elias CJ and Tipping $\mathrm{J}$ have been further criticised for asserting that their judgment did not challenge parliamentary sovereignty without fully exploring that issue..$^{71}$

\section{F Thoburn and Pora}

The Thoburn decision causes us to see Pora in a new light. Were the judgments of Elias CJ, Tipping and Thomas JJ simply precursors to Thoburn? If they were, the judgments achieve a sort of retrospective validation, although the logic of Elias $\mathrm{CJ}$ and Tipping $\mathrm{J}$ is still open to criticism. This question receives different answers depending on how one views Thoburn's treatment of the relationship between implied repeal and parliamentary sovereignty.

On the view that Thoburn limits parliamentary sovereignty by taking away Parliament's power to repeal fundamental rights by implication, the judgments of Elias CJ, Tipping and Thomas JJ were perfectly in line with Thoburn. In enacting the Criminal Justice Amendment Act, Parliament tried impliedly to repeal a fundamental right. The Court was therefore entitled to decline to apply the amendment.

A difficulty with this analysis is that the Thoburn test for the repeal of constitutional statutes says that they may be repealed either expressly or "by words so specific that the inference of an actual determination to effect the result contended for was irresistible". ${ }^{72}$ It is arguable that the amending provision in Pora was worded strongly enough to meet this test. Nevertheless, if we accept this view of Thoburn as a vindication of Pora, the judgments of Elias CJ, Tipping and Thomas JJ begin to seem more legitimate.

\section{NEW ZEALAND BILL OF RIGHTS ACT 1990}

\section{A Statutory Interpretation}

The enactment of the New Zealand Bill of Rights Act 1990 brought about a shift in the way New Zealand statutes are interpreted. The Bill of Rights Act provides that "wherever an enactment can be given a meaning that is consistent with the rights and freedoms contained in this Bill of

69 Anita Killeen, Richard Ekins and John Ip "Undermining the Grundnorm?" [2001] NZLJ 299, 301.

70 Killeen, Ekins and Ip, above n 69, 301.

71 Butler, above n 11, 593.

72 Thoburn v Sunderland City Council, above n 8, para 63 Laws LJ. 
Rights, that meaning shall be preferred to any other". ${ }^{73}$ Any limitation on rights is therefore discouraged, although where a statutory provision is irreconcilable with the Bill of Rights Act, the irreconcilable provision is to prevail. ${ }^{74}$ To determine the effects on New Zealand law of the adoption of a Thoburn-type revision of implied repeal, it is necessary first to examine the effects the Bill of Rights Act has on statutory interpretation. It is arguable that the Bill of Rights Act already has the same effect as a revision of implied repeal. To assess this argument one must consider the legal effect of that Act and the scope of the rights it protects.

\section{B Must the Common Law be Consistent with the Bill of Rights Act?}

Acts of the judiciary must conform with the Bill of Rights Act. ${ }^{75}$ It is therefore arguable that the development and application of the common law, as an act of the judiciary, must be done consistently with that Act. A Bill of Rights Act-consistent interpretation of the doctrine of implied repeal may be that the doctrine simply does not apply when the earlier legislation relates to a right that is protected by the Bill of Rights Act.

This argument contains a number of flaws. While there is certainly authority for the proposition that the common law must develop in accordance with the rights contained in the Bill of Rights Act, ${ }^{76}$ it is not clear that existing inconsistent doctrines of the common law must immediately be revised..$^{77}$

Furthermore, this sort of revision would appear to be forbidden by the Bill of Rights Act itself. If implied repeal were to cause a provision that contained protected rights to be ineffective, it would really be the later statute that is inconsistent with the Bill of Rights Act, not the doctrine of implied repeal itself. Implied repeal is merely a mechanism by which statutes are applied. That later statute may be inconsistent with the Bill of Rights Act, but the Bill of Rights Act demands that inconsistent statutes be given effect in spite of that inconsistency. ${ }^{78}$ To argue that implied repeal must change in order to avoid such situations seems to ignore the policy of the Bill of Rights Act. The argument that implied repeal must be revised in order to comply with the Bill of Rights Act therefore fails.

73 New Zealand Bill of Rights Act 1990, s 6.

74 New Zealand Bill of Rights Act 1990, s 4.

75 New Zealand Bill of Rights Act 1990, s 3.

76 Lange v Atkinson [1997] 2 NZLR 22, 32 (CA) Elias J.

77 See for example, Paul Rishworth and others The New Zealand Bill of Rights (Oxford University Press, Oxford, 2003) 102-108.

78 New Zealand Bill of Rights Act 1990, s 4. 


\section{Does the New Zealand Bill of Rights Act Effectively Replace Implied Repeal?}

There is a second way in which it may be argued that the Bill of Rights Act has an effect similar to a Thoburn-type revision of implied repeal. When statutes are inconsistent, one way of resolving the inconsistency is to treat the earlier statute as impliedly repealed. Another way is to uphold the statute that limits rights to the least extent, irrespective of the order of enactment of the relevant Acts.

$R v$ Allison is an example of this second mode of statutory interpretation. ${ }^{79}$ The issue in Allison was whether results from drug tests done on prison inmates for disciplinary purposes could be used as evidence at a bail hearing. Two statutes suggested different answers. The later statute allowed the court in a bail hearing to receive any relevant information, "whether or not it would otherwise be admissible in a court of law". ${ }^{80}$ The earlier statute provided that the results from drug tests were not to be used in other proceedings under that statute or any other. ${ }^{81}$ The Crown argued that the later statute impliedly repealed the earlier one pro tanto, with the result that the later statute created a specific exception to the general rule that results from prison inmate drug tests could not be used in other proceedings. ${ }^{82}$

The Court declined to apply the doctrine of implied repeal. ${ }^{83}$ In fact, the judgment barely even mentions it. Instead, the Court resolved the inconsistency by using the Bill of Rights Act. Courts are required to prefer statutory interpretations that do not limit the rights contained in the Bill of Rights Act. ${ }^{84}$ The Court found that it was required to apply the terms of the statute that involved the least interference with the rights of prisoners, notwithstanding that that statute had been enacted earlier. ${ }^{85}$

If the Bill of Rights Act always allows courts that are considering inconsistent rules to prefer the statute that erodes rights the least, whatever the respective dates of enactment of the inconsistent statutes, the proposed revision of implied repeal in Thorburn would have little effect. Many cases where the revised doctrine of implied repeal might apply would simply reach the issue. Be that as it may, the Bill of Rights Act is incapable of replacing the doctrine of implied repeal in all situations where it might apply. Statutory inconsistency may vary in intensity. Situations such as Allison are at the lower end of the scale: while Parliament possibly intended the later statute to override the earlier

$79 R$ v Allison [2002] 1 NZLR 697 (CA).

80 Bail Act 2000, s 20(1).

81 Penal Institutions Act 1954, s 36BD.

82 K Raftery (Crown Solicitor) "Synopsis of Submissions on Behalf of the Crown" Court of Appeal File CA 387/01 ( $R$ v Allison [2002] 1 NZLR 697 (CA)), para 26.

$R v$ Allison, above $\mathrm{n} 79$, para 24 Baragwanath $\mathrm{J}$ for the Court.

84 New Zealand Bill of Rights Act 1990, s 6.

$85 R v$ Allison, above $\mathrm{n} 79$, paras 21-22 Baragwanath $\mathrm{J}$ for the Court. 
one, it is also possible that the two statutes were intended to cover entirely different situations. Applying the Bill of Rights Act is an acceptable way of choosing between the two statutes.

Where statutes are sharply inconsistent, however, using the Bill of Rights Act in this way is not acceptable. In situations such as Pora, there can be no doubt that Parliament intends the later statute to apply instead of the earlier one. In Pora, Elias CJ and Tipping $\mathrm{J}$ in fact argued that the Bill of Rights Act demanded that they should apply the earlier statute. ${ }^{86}$ However, Keith, Gault and McGrath JJ rejected this approach, finding that an interpretation that gave the amending provision a purely prospective effect would not be permissible. ${ }^{87}$

The adoption of a Thoburn-type rule would therefore have an effect on New Zealand law, because it would render implied repeal ineffective in cases like Pora. Furthermore, the class of rights that Thoburn would designate as constitutional is broader than the class of rights that the Bill of Rights Act protects. ${ }^{88}$ Nevertheless, that the courts are prepared partially to replace implied repeal with a test that favours an interpretation that gives the fullest expression to individual rights suggests that New Zealand's attachment to parliamentary sovereignty is waning. A new rule of statutory interpretation that protects constitutional statutes from implied repeal is possibly the next logical step.

\section{NEW ZEALAND'S CONSTITUTIONAL STATUTES}

\section{A The Thoburn Test}

If New Zealand adopts the rule that constitutional statutes cannot be impliedly repealed, it will be necessary to identify which statutes count as constitutional in the New Zealand context. The test proposed in Thoburn will be useful, but the constitutional differences between New Zealand and the United Kingdom must be borne in mind.

The Thoburn decision holds that constitutional statutes must be distinguished from ordinary ones "on a principled basis". ${ }^{89}$ Unfortunately, the test that Thoburn proposes does not give much guidance as to what the relevant principles might be or as to how those principles might be applied in the New Zealand context. A test that holds that a constitutional statute "conditions the legal relationship between citizen and state in some general, overarching manner, or ... enlarges or diminishes the scope of what we would now regard as fundamental constitutional rights" leaves the matter almost entirely to judicial decision..$^{90}$

\footnotetext{
$86 R$ v Pora, above $\mathrm{n} 6$, paras 32-35 Elias CJ and Tipping J.

$87 R v$ Pora, above $\mathrm{n} 6$, para 111 Keith, Gault and McGrath JJ. 


\section{B The European Communities Act}

The particular statute that Thoburn addressed was constitutional because it "incorporated the whole corpus of substantive Community rights and obligations, and gave overriding domestic effect to the judicial and administrative machinery of Community law". ${ }^{91}$ While Laws LJ gives weight to the factor that the Act in effect created a new legal system separate from existing United Kingdom law, it is not this factor alone that gives the Act its status. Laws LJ also names statutes such as the Magna Carta 1297 and the Bill of Rights 1688, which involve no international obligations, as examples of constitutional statutes.

However, the usefulness of the European Communities Act as an example of a constitutional statute may be somewhat limited in the New Zealand context. By virtue of being contained in that Act, a number of quasi-rights (such as the right to use the metric system) count as constitutional in the United Kingdom. It does not follow that such quasi-rights would automatically qualify for constitutional status in New Zealand. Rights such as the right to use the metric system are constitutional not because of their own importance, but because of the importance of the statute that contains them. The European Communities Act created a new legal system. ${ }^{92}$ New Zealand simply does not have any comparable Acts.

\section{The Two Limbs of Laws LJ's Test}

It is tempting to conclude that the identification of New Zealand's constitutional statutes must be a search for statutes that fall under the second limb of Laws LJ's test, that is, constitutional statutes are those that "[enlarge] or [diminish] the scope of what we would now regard as fundamental constitutional rights". ${ }^{93}$ However, this conclusion may be somewhat hasty. New Zealand does not have any statutes with the international significance of the European Communities Act, but it does have statutes that, like the European Communities Act, "[condition] the legal relationship between citizen and state in some general, overarching manner". ${ }^{94}$ Enactments such as the Electoral Act 1993, the conveniently named Constitution Act 1986, or even the Income Tax Act 2004 could fall under the first limb of Laws LJ's test, but arguably do not fall under the second limb. Whether such statutes concern "what we would now regard as fundamental rights" depends very much on one's definition of "fundamental rights". 95

\footnotetext{
91 Thoburn v Sunderland City Council, above n 8, para 62 Laws LJ.

92 Thoburn v Sunderland City Council, above n 8, para 62 Laws LJ.

93 Thoburn v Sunderland City Council, above n 8, para 62 Laws LJ.

94 Thoburn v Sunderland City Council, above n 8, para 62 Laws LJ.

95 Thoburn v Sunderland City Council, above n 8, para 62 Laws LJ.
} 
Whether these enactments qualify as constitutional under Laws LJ's test is one question, but whether New Zealand law is prepared to recognise them as such, particularly if the word "constitutional" now has certain consequences, is another. It is certainly arguable that the United Kingdom is more prepared than New Zealand to bestow entire Acts with constitutional status. New Zealand has seen no constitutional developments significant enough to dislodge the Diceyan idea that the constitution is contained throughout its whole body of law, and so-called "constitutional" Acts are really just the same as other Acts. ${ }^{96}$ The United Kingdom, on the other hand, has recognised just how important a single statute can be via the Thoburn decision.

\section{Constitutional Provisions}

The most likely approach of the New Zealand courts is therefore to identify rights that are regarded as constitutional and to hold that provisions embodying those rights cannot be impliedly repealed. Pora can be seen as an application of this approach. The relevant issue was the status of the prohibition of retrospective penalties, rather than the status of the Criminal Justice Act. The factors that led Elias CJ and Tipping $J$ to conclude that the prohibition was so fundamental that it could not be impliedly repealed included that the prohibition was incorporated in a number of pieces of New Zealand legislation, including the Bill of Rights, and that in giving effect to the provision New Zealand was fulfilling its obligations under the International Covenant on Civil and Political Rights. ${ }^{97}$

A similar approach is apparent in Thomas J's judgment. Thomas $\mathrm{J}$ demonstrates the fundamental nature of the prohibition on retrospective penalties by referring not only to legislation confirming the prohibition, but also to judgments that have consistently condemned retrospective penalties and retrospectivity generally. ${ }^{98}$

Even the judgment of Keith, Gault and McGrath JJ, that ultimately decided that fundamental provisions were vulnerable to implied repeal, can be of assistance in determining how constitutional rights are to be identified. The judges were in no doubt that the prohibition on retrospectivity was a "basic rule of criminal justice",99 and both national and international law had declared the prohibition to be a fundamental right. ${ }^{100}$

Exactly which rights are so important that they could protect a provision from implied repeal is still unclear. Laws LJ has been criticised for not clarifying the status of rights like the rights to

96 Albert Venn Dicey Introduction to the Study of the Law of the Constitution (10 ed, MacMillan Education, Basingstoke, 1959) 88.

$97 R v$ Pora, above n 6, paras 20-21 Elias CJ and Tipping J.

$98 \quad R v$ Pora, above n 6, paras 154-156 Thomas J.

$99 R v$ Pora, above n 6, para 61 Keith, Gault and McGrath JJ.

$100 R v$ Pora, above n 6, para 63 Keith, Gault and McGrath JJ. 
education or to medical services. ${ }^{101}$ Whether these rights, or other quasi-rights like electoral rights, are now capable of insulating provisions against implied repeal is an open question. For example, Parliament currently could impliedly repeal section 268 of the Electoral Act, which provides that six other sections of the Electoral Act can be repealed or amended only by a 75 per cent majority, simply by purporting to change one of those six sections by a simple majority. ${ }^{102}$ This action would be politically almost impossible, ${ }^{103}$ but a rule prohibiting the section's implied repeal would also make the action legally impossible. It is therefore entirely possible that a Thoburn-type rule could have a broad potential application in New Zealand. Whether the New Zealand courts would accept such a breadth of application is a separate issue.

\section{IS A REVISION OF IMPLIED REPEAL DESIRABLE?}

\section{A Dicey and Parliamentary Sovereignty}

Constitutional law does not begin and end with Dicey, but the constitutional philosophies of both the United Kingdom and New Zealand are rooted in the principles that Dicey set out. ${ }^{104}$ The most important Diceyan principle in the present context is the principle of parliamentary sovereignty, which Dicey describes as "the very keystone of the constitution". ${ }^{105}$ The doctrine holds that legislation, as the will of Parliament, is the highest possible law. Dicey also holds that the power of Parliament to make law may not be limited by the acts of its predecessors; ${ }^{106}$ so implied repeal is a necessary corollary of parliamentary sovereignty.

Thoburn still allows Parliament to repeal constitutional statutes expressly; so it is arguable that any limit on parliamentary sovereignty is negligible. Laws LJ would presumably support this argument, so keen is he to maintain that his reformulation "preserves the sovereignty of the legislature". ${ }^{107}$ It is technically true that if the courts decline to interpret a statute in a way that impliedly repeals a fundamental right, Parliament can always expressly repeal it. If there are two ways in which Parliament may do something, are the courts really limiting Parliament's power if they tell Parliament that only one of those ways remains an option? The answer to this question depends on one's perspective. On one view, Parliament can still do exactly what it could always do, that is, repeal any statute; so parliamentary sovereignty is unaffected. Nevertheless, the better view

101 Marshall, above n 21, 495.

102 Constitutional and Administrative Law in New Zealand, above n 10, 115.

103 Constitutional and Administrative Law in New Zealand, above n 10, 134.

104 See Elliot, above n 26, 546.

105 Dicey, above n 96, 70.

106 Dicey, above n 96, 64.

107 Thoburn v Sunderland City Council, above n 8, para 64 Laws LJ. 
holds that if the courts tell Parliament that it cannot do something, parliamentary sovereignty has by definition been limited.

\section{B Do "Constitutional" Laws Exist in the Diceyan Conception?}

A necessary implication of the proposition that legislation enacted by Parliament is the highest form of law is that all legislation has equal status, because it has all been enacted in the same way. Dicey holds therefore that "no law can be any more sacred and immutable than any other". ${ }^{108}$ Dicey rejects the idea that there are particular laws that have a special status because of their subject matter. "[S]o-called constitutional or fundamental laws" are subject to the same legislative processes as any other law. ${ }^{109}$

For Dicey, a key feature of the English constitution is that there is no formal distinction between constitutional and non-constitutional laws. ${ }^{110}$ No laws declare themselves to be constitutional. Nevertheless, Dicey does not hold that a search for constitutional principles in English law must fail. English constitutional principles are "the result of judicial decisions determining the rights of private persons in particular cases ... . Our constitution, in short, is a judge-made constitution". 111

Thoburn therefore seems to conflict with Dicey by virtue of the limitation on parliamentary sovereignty and of the creation of a hierarchy of statutes. Conscious of this apparent conflict, Laws $\mathrm{LJ}$ is at pains to deny it, pointing out that his decision is "wholly [consistent] with constitutional principle". ${ }^{112}$ There is some truth in this argument. Dicey maintains that constitutional development is the role of the courts; so arguably Laws LJ was merely carrying out his constitutional function in imposing a limit on parliamentary sovereignty. Laws LJ would certainly agree with this assessment, maintaining as he does that the courts are the body to which "the scope and nature of parliamentary sovereignty are ultimately confided". ${ }^{113}$

\section{Natural Rights and Ronald Dworkin}

Although Thoburn does not require us to eliminate a Diceyan constitutional framework entirely, Dicey's reliance on parliamentary sovereignty as "the keystone of the constitution" suddenly seems to paint an inadequate constitutional picture. ${ }^{114}$ Thoburn's emphasis on rights as fundamental means

\footnotetext{
108 Dicey, above n 96, 89.

109 Dicey, above n 96, 88

110 Dicey, above n 96, 89.

111 Dicey, above n 96, 195-196.

112 Thoburn v Sunderland City Council, above n 8, para 59 Laws LJ.

113 Thoburn v Sunderland City Council, above n 8, para 60 Laws LJ.

114 Dicey, above n 96, 70 .
} 
that the Diceyan theory must be supplemented, and perhaps in some areas supplanted, by a theory that gives rights a central position.

Ronald Dworkin's conception of legality fits particularly well with Thoburn. Dworkin holds that when judges decide cases, they apply a mixture of rules, which are embodied in legislation, and principles. Principles have a different character from rules. Unlike rules, which are "all or nothing" in application, principles can apply to a greater or lesser degree depending on circumstances. ${ }^{115}$ Principles have very general formulations. For example, "people may not profit from their wrongs" is a principle. ${ }^{116}$ Principles have an application that is broad but at the same time contingent.

Dworkin's theory of principles helps to elucidate the Thoburn conundrum because one of the characteristics of principles is that they can potentially override clear statutory language, particularly in hard cases. ${ }^{117}$ That is, there are situations where despite the existence of legislation that on its face governs the case that has arisen, a source of law other than legislation can potentially decide the issue. Thoburn contemplates one such situation, in which the words of a later statute are clearly inconsistent with the words of an earlier one, yet the special character of the earlier statute means that its provisions withstand implied repeal. The source of the earlier statute's special character must be external to legislation, yet still part of the law. That is, a theory that holds that there are two levels of statute must originate from principles.

Dworkin holds that principles must come from rights, because rights already exist in our political history. Judges applying principles in preference to rules cannot be accused of judicial originality, because the principles that they apply have been part of the law ever since people have had individual rights. ${ }^{118}$ Legal systems therefore have two coexistent sources of law: legislation and individual rights. When those sources conflict, the question arises as to which source should prevail.

\section{Statutory Interpretation}

Dworkin implicitly rejects the idea that courts should defer to parliamentary sovereignty when interpreting statutes, particularly where constitutional rights are involved. He holds that where a statute potentially restricts a constitutional right courts must do more than simply construct an abstract notion of parliamentary intent. Rather, courts must favour a statutory interpretation that "more satisfactorily ties the language the legislature used to its constitutional responsibilities". 119 For some critics, this approach to statutory interpretation merges political and legal theory to an

115 Ronald Dworkin Taking Rights Seriously (Harvard University Press, Cambridge (Mass), 1977) 25.

116 Dworkin, above n 115, 23.

117 Dworkin, above n 115, 23.

118 Dworkin, above n $115,87$.

119 Dworkin, above n 115, 108. 
unacceptable degree, because the constitutional principles that Dworkin would have the courts apply are more correctly seen as political and moral concepts, as opposed to legal ones. ${ }^{120}$ Nevertheless, the influence of Dworkin's rights-based interpretation principles is apparent in both Thoburn and Pora.

Thoburn can be seen as an example of this kind of statutory interpretation because it is an example of the courts giving effect to parliamentary intent only so far as that intent is constitutionally legitimate. The abrogation of constitutional rights by anything less than a clear legislative statement sits uncomfortably with Parliament's constitutional responsibilities.

Similarly, while three Pora judges rejected any suggestion that constitutional rights enjoy any sort of superior legal status, the judgment of Elias CJ and Tipping J and the judgment of Thomas J show a strong Dworkin influence. Thomas J in particular borrows much from Dworkin.

For Thomas J, the starting point of interpreting statutes is the proposition that "fundamental rights are to be taken seriously."121 For the purposes of implied repeal, the most important consequence of this proposition is that the courts will not accept that parliament intended to curb fundamental rights unless that intention is stated in clear terms. ${ }^{122}$ Implied repeal is simply not a sufficiently clear statement of intention.

Reading Thomas J's judgment in the factual context of Pora, it seems that the only statement of parliamentary intent that would satisfy his Honour's test would be an express repeal. The retrospective amendments to the Criminal Justice Act were so clearly worded that there could be no real doubt about Parliament's intention. The result is that while Thomas $\mathrm{J}$ states that his decision does not challenge parliamentary sovereignty because Parliament is still free to abrogate fundamental rights as long as it does so expressly, ${ }^{123}$ his decision clearly places a limit on the power of Parliament. Thomas J's decision tells Parliament that there is a particular act that it cannot do, namely that of abrogating fundamental rights without an express repeal, even if the abrogation is by clear implication.

\section{E What are Parliament's "Constitutional Responsibilities"?}

Dworkin's statement that statutes must be interpreted in the context of Parliament's constitutional responsibilities seems logical when applied to a system where there is a written constitution. The difficulty in a system of parliamentary sovereignty, without a written constitution, is that Parliament does not necessarily have any constitutional responsibilities at all. Individual

\footnotetext{
120 Richard Ekins "Judicial Supremacy and the Rule of Law" (2003) 119 LQR 127, 130-131.

$121 R v$ Pora, above n 6, para 120 Thomas J.

$122 R v$ Pora, above n 6, para 120 Thomas J.

$123 R v$ Pora, above n 6, para 121 Thomas J.
} 
governments may well have political responsibilities, but in countries where there is no written constitution and legislation is the highest form of law, it seems curious to suggest that Parliaments are constitutionally bound to do anything.

Nevertheless, a revision of Dworkin's theory to make it applicable to countries with Diceyan constitutions could save the Thoburn decision from accusations of excessive judicial activism. Instead of focusing on the constitutional responsibilities of Parliament, courts must focus on their own constitutional responsibilities. To identify these responsibilities Dicey is useful once again. Dicey maintains that constitutional development is the traditional task of the courts. ${ }^{124}$ It would seem that even for Dicey the principles of the constitution originate in the common law.

Individual rights have a fundamental role in Dicey's constitutional theory. The United Kingdom's constitutional arrangements have developed as a result of the courts determining the rights of individuals in many different situations. It is because of these decisions that there are constitutionally recognised rights such as the right to personal liberty and the right of public meeting. ${ }^{125}$

On the Diceyan view, individual rights are the source of the constitution; they do not flow from it. ${ }^{126}$ In this sense, the Diceyan conception of constitutional arrangements is entirely compatible with Dworkin's rights-based theory. The two views diverge when we consider what the relationship between the sovereignty of Parliament and the protection of these rights ought to be. Dworkin sees rights as trumps that can override even express statutory enactments. ${ }^{127}$ In contrast, however Dicey while might view the role of judges as being to develop the constitution, he is clear that legislative supremacy is inviolable. ${ }^{128}$ The Thoburn decision represents a middle ground between these two poles. The decision preserves Parliament's power to abrogate constitutional rights, but specifies that any abrogation must be express. A conventional Diceyan approach would allow Parliament to legislate away constitutional rights either expressly or impliedly. A rule that holds that constitutional rights are not subject to implied repeal is certainly a move away from Dicey and towards Dworkin.

One possible escape from the impasse between Dicey and Dworkin is to contend that Dicey goes no further than to describe the constitutional situation in the United Kingdom at a particular time, while Dworkin is proposing a constitutional ideal. Parliamentary sovereignty might have been an absolute in Dicey's time, but in the intervening years the courts have performed their constitutional task of developing the constitution, with the result that the constitution now begins to

124 Dicey, above n 96, 196.

125 Dicey, above n 96, 195.

126 Dicey, above n 96, 203.

127 Dworkin, above n 115, 108.

128 Dicey, above n 96, 90. 
resemble Dworkin's ideal. Parliamentary sovereignty now has certain qualifications, and a revision of implied repeal is one of them.

\section{F Can a Hierarchy of Norms be Justified?}

It may be that Diceyan constitutions where parliamentary sovereignty is unqualified no longer exist, at least in the United Kingdom and New Zealand. Whether or not this conclusion is correct, there is a prior issue as to whether such a situation is desirable.

Written constitutions, Dworkin's theory that individual rights can override legislation, and the Thoburn decision all share a common idea: that there are situations in which legislation is ineffective. To this extent they attract a common objection: how can we justify preventing Parliament from doing what it wants? Laws LJ in Thoburn offered no argument to support a claim that somehow human rights legislation is enacted more forcefully than ordinary legislation, ${ }^{129}$ and presumably he would argue that the manner of such legislation's enactment is beside the point. The higher status of constitutional legislation comes from the common law. ${ }^{130}$ What Laws LJ does not mention is that the common law lacks the full backing of democracy.

In contrast, the proposition that legislation enacted by Parliament is and should continue to be the highest form of law has one very important point in its favour: Parliament is representative of the population, and legislation is therefore representative of the population's will, if only formally so. If we allow something to defeat legislation, whether that something be a written or unwritten constitution or a theory of natural rights, we are in effect allowing something to defeat the will of the population.

\section{G Waldron and the Illegitimacy of Entrenchment}

Jeremy Waldron holds that there can be no justification for the proposition that legislation is ineffective when it conflicts with constitutional principles. Waldron concedes that the idea that constitutional rights should be protected from conflicting legislation has a strong initial appeal. At least in democracies, written constitutions are democratically adopted, and are the result of people having a "lucid moment", in which they elect to bind themselves in order that they shall not commit rights-infringements later on. ${ }^{131}$ People's election to bind themselves can be seen as the ultimate exercise of personal autonomy, as opposed to a restriction on it.

Waldron concedes that entrenched constitutions are initially appealing. ${ }^{132}$ Nevertheless, Waldron maintains that the argument is fundamentally flawed. First, the "lucid moment" argument

\footnotetext{
129 Marshall, above n 21, 496.

130 Thoburn v Sunderland City Council, above n 8, para 60 Laws LJ.

131 Jeremy Waldron Law and Disagreement (Oxford University Press, Oxford, 1999) 261.

132 Waldron, above n 131, 274.
} 
is correct only if the behaviour that the population seeks to avoid is really behaviour that they will not ever want to engage in. If the population enacts an entrenched constitution on a whim, or even if it is wavering in its commitment, there can be no real justification for allowing it to bind its future behaviour. ${ }^{133}$

Secondly, even if the enactment of an entrenched constitution is a true reflection of the will of the population for the present and the future, this argument ignores the reality that the composition of a population is not constant. The population that enacted the original constitution will eventually be replaced by future generations. While there may be a sound argument that one group of individuals can enact legislation that curtails their own future actions, that argument cannot justify that group of individuals curtailing the future actions of a different group. ${ }^{134}$

\section{H How Does Waldron's Argument Affect the Thoburn Decision?}

Waldron's argument certainly gives proponents of entrenched constitutional rights reason to doubt their convictions. Moreover, if Waldron is correct, the Thoburn decision is even less advisable than entrenched written constitutions, which in theory had democratic backing at some stage, whatever the current position may be. The constitutional status that Thoburn gives some statutes never had any such backing. These statutes owe their special status to the judiciary, a group that by no means represents the will of the population.

If Waldron is correct, the Thoburn decision seems indefensible. However, it is possible that Waldron is not correct, or at least that his theory lacks a degree of political reality. Waldron's conception of the relationship between Parliament and the general population seems somewhat idealised, in that it seems to assume that the will of the population finds a direct translation in Acts of Parliament. It follows from this assumption that when Parliament finds that it cannot do what it wants because it is constrained by a previously entrenched constitution, it is really the will of the population that is being thwarted. But this assumption is incorrect, or at least may be incorrect in some situations.

Waldron's argument rests on the premise that if a particular government starts abrogating individual rights against the will of the populace, then the populace is free to elect another government that will not abrogate rights. What this premise does not take into account is that whatever their political philosophies, governments often find it expedient to curtail constitutional rights. Furthermore, while people might not agree with the actions of governments in restricting rights, such actions will not normally cause governments to lose elections. It is this sort of concern that prompts commentators to stress the role of the courts in protecting rights. ${ }^{135}$ Waldron's

133 Waldron, above n 131, 269.

134 Waldron, above n 131, 274.

135 See for example, $R v$ Pora, above n 6, para 119 Thomas J; "Sovereignty in the $21^{\text {st }}$ Century", above n 52 , 160 . 
argument that constitutional entrenchment is an unacceptable fetter on the autonomy of the population may work as a matter of pure logic, but the argument loses some force when the will of the population is subsumed by political reality.

\section{A Constitutional Compromise}

In a sense, the proposition that constitutional rights cannot be impliedly repealed represents a mid-point between entrenched constitutions and undiluted versions of parliamentary sovereignty. A limit on implied repeal is a relatively minor limit on Parliament's power because Parliament can still expressly repeal any statute. However, the courts' insistence that if Parliament wants to abrogate rights it must do so by express repeal means that any such abrogation will be subject to public scrutiny, and is therefore much more likely to have legitimate democratic backing.

This revision of implied repeal can be seen as a greater limit on Parliament's political sovereignty than on its legal sovereignty. The actual resistance a Parliament is likely to face if it wants to abrogate a constitutional right will be political, rather than legal. Legally, Parliament can still repeal whatever it likes. This situation is reminiscent of the situation in relation to the Canadian Charter of Rights and Freedoms. ${ }^{136}$ Canadian Parliaments can limit the jurisdiction of Canadian courts to strike down legislation that is inconsistent with the rights protected by the Charter by specifying that a particular piece of legislation is to apply notwithstanding the other provisions of the Charter. ${ }^{137}$ The legal sovereignty of the Canadian Parliament is therefore preserved, because it retains the power to override the Charter. Nevertheless, the Canadian Parliament must confront its democratic responsibilities squarely if it wishes to exercise that legal sovereignty. ${ }^{138}$

The intersection of political and legal sovereignty that both the Canadian Charter and the Thoburn decision address can be seen as encouraging a dialogue between legislatures and courts. ${ }^{139}$ A refusal by common law courts to apply the doctrine of implied repeal to a constitutional provision forces Parliament to decide whether it can bear the political cost of expressly repealing that provision. The public debate that will follow the action of the courts ought to be an indication to Parliament of what its democratic responsibilities are in the particular situation. The result will be that abrogation of constitutional rights will not occur without careful consideration.

136 Canadian Charter of Rights and Freedoms, Part I of the Constitution Act 1982 (Canada Act 1982 (UK), sch B).

137 Canadian Charter of Rights and Freedoms, s 33.

138 Peter W Hogg and Allison A Bushell "The Charter Dialogue Between Courts and Legislatures" (1997) 35 Osgoode Hall LJ 75, 82-85.

139 Hogg and Bushell, above n 138, 81. 


\section{CONCLUSION}

The proposition in Thoburn that there are constitutional statutes that cannot be impliedly repealed, is arguably a limit on parliamentary sovereignty, although it is by no means a denial of it. To the extent that Thoburn limits parliamentary sovereignty, it forces a revision of the traditional Diceyan picture of the constitution. The desirability of this revision is open to debate. Pure parliamentary sovereignty has the weight of democracy behind it, but the counter-argument is that the field of constitutional rights is an area where the will of the populace is easily distorted.

The debate over whether a higher-law jurisprudence is appropriate will continue, but in practice it is clear that legal systems are moving inexorably towards entrenched or semi-entrenched constitutional rights. The current unsettled state of New Zealand law is undesirable, but the Thoburn decision, along with the increasing shift towards a rights-based statutory interpretation, makes it highly likely that New Zealand will soon unequivocally adopt the proposition that fundamental rights cannot be impliedly repealed. 